\title{
The Literary Response to the Holocaust and the Transformation of the Reader into a Messenger
}

\author{
David Patterson
}

Citation: Patterson, David. 2021. The Literary Response to the Holocaust and the Transformation of the Reader into a Messenger. Humanities 10: 97. https://doi.org/10.3390/h10030097

Received: 23 July 2021

Accepted: 28 July 2021

Published: 11 August 2021

Publisher's Note: MDPI stays neutral with regard to jurisdictional claims in published maps and institutional affiliations.

Copyright: (C) 2021 by the author. Licensee MDPI, Basel, Switzerland. This article is an open access article distributed under the terms and conditions of the Creative Commons Attribution (CC BY) license (https:// creativecommons.org/licenses/by/ $4.0 /)$.
Ackerman Center for Holocaust Studies, University of Texas at Dallas, Richardson, TX 75080-3021, USA; david.patterson@utdallas.edu

\section{Introduction}

"The greatest mitzvah," Lily Lerner remembers what her mother taught her, "is to accompany a dead person to burial" (Lerner 1980, p. 35). Therefore, later in her life she continued to observe one of her first lessons in life, accompanying the dead to a burial that is never done with. Indeed, one of the defining features of the Holocaust is the murder of Jewish death, a point that Yitzhak Katznelson makes in his Vittel Diary: "Throughout the era of Hitler, the agent of the whole non-Jewish world, not a single Jew died, they were just murdered, murdered" (Katznelson 1972, p. 228). In the words of Primo Levi, who understood more than anyone the meaning of the Muselmann, "one hesitates to call them living: one hesitates to call their death death" (Levi 1990, p. 90). With the eradication of Jewish death and the obliteration of Jewish burial, every Jew-indeed, every human being-is summoned to become a member of a Chevrah Kadisha, the Holy Burial Society entrusted with the care of the dead, eternally accompanying the dead to their burial-not within the earth, for that was denied them, but within each of us.

"They and the others are buried within me," Ka-tzetnik 135633 states it. "Over their ashes I vowed to be a voice to them, and when I left Auschwitz they walked with me, they and the soundless Auschwitz blocks, the soundless crematorium, the soundless horizons, and at the front the mountain of ash to show me the way" (Ka-tzetnik 135633 1989, p. 18). Just as the dead are both within us and beyond us, in a sky transformed into a cemetery, the vow that comes to the lips of the survivor who engages in a literary response to the Holocaust comes not only from within but from beyond. It comes not as an assertion of the individual's will but as a response to a summons to bear witness, despite the will of the individual. The summons is to remember; the temptation is to forget.

When Germaine Tillion had the opportunity to return to Ravensbrück and recover the evidence of what took place there, she had to struggle against the temptation to forget. "It took an enormous effort," she writes, "to avoid trying to forget this world of horror" (Tillion 1975, p. 16). If it were only facts that had to be remembered, the issue of forgetting would not be so urgent. Facts are easily memorized and regurgitated. But, more than the facts, there are people whose memory cries out to be attested to; to forget them would be to turn one's face away from them. That is where the literary response to the Holocaust comes in: it transcends the factual to articulate the needful. "I, too, want to forget," writes Olga Lengyel. "But ... in setting down this personal record I have tried to carry out the mandate given to me by the many fellow internees at Auschwitz who perished so horribly. This is my memorial to them" (Lengyel 1972, p. 216). The notion of a mandate is important here, because it invokes the significance of this testimonial response to the Holocaust, which derives neither from the one who remembers nor from dead remembered. Along with the dead who summon the testimony is the Commanding Voice of Another, who makes this literary response, this testimony, matter.

In their literary testimonies survivors often refer to Another, who lays claim to them as witnesses. Paul Trepman, for example, writes, "Perhaps Providence intended that I ... should live to record this one event which otherwise might have been omitted 
from mankind's testimony against Adolf Hitler" (Trepman 1978, p. 138). Ana Vinocur states it more firmly, more succinctly: "God chose us to be the witnesses of this story" (Vinocur 1976, p. 134). As the witness of the story, the survivor is more than the teller of the tale; she is the respondent to the Voice that summons the tale, so that the tale of the Shoah includes the tale of the Voice Himself. This is why Holocaust testimony, especially in its literary mode, entails not only the recounting of events but also the recovery of a tradition through this narrative-that is what makes it testimony. The literary response to the Holocaust arises in a response to a summons: transmit the message. In this the Chosen have no choice-even if no one will listen.

"I wanted to return to Sighet," explains Moshe the Beadle in Elie Wiesel's Night, "to describe to you my death so that you might ready yourselves while there is still time .... Only no one is listening to me" (Wiesel 2006, p. 7). In these few words we have a paradigm for the dilemma of the survivor who has a tale to tell. He comes to us with a message from a mass grave that covers a continent. He warns us of the collapse of meaning and the mutilation of the divine image within the human being taking place all around us, both then and now. Most of us, then and now, do not listen. Those who listen cannot understand. For, unlike the survivor, we have not seen the inside of our own grave or the visage of a corpse staring back at us from a mirror (Wiesel 2006, p. 115). And yet through his literary response to this Event he transforms us into messengers who, like the survivor, must deliver a message and sound a warning. It is a singular message that brings with it a universal warning. There, in this tension between the unique and the universal, lies the difficulty in the transmission of this literary testimony that transforms its reader into a messenger.

\section{The Transformation of the Reader into a Messenger}

Elie Wiesel has said that the tale "belongs as much to the listener as to the teller. You listen to a tale, and all of a sudden it is no longer the same tale" (Wiesel 1970a, p. 107). And so it is with the literary response to the Holocaust: the tale belongs as much to the reader as it does to the author, with all the ethical implications of the transformation of the reader into a witness. Why? Because each offering and receiving of the literary testimony becomes part of the testimony itself. Like the Event, the testimony is already within us. "We flounder," writes Terrence Des Pres, "in a torment having nothing to do with us yet felt in some strange way to be very much a part of our deepest, most secret being. The terror of the camps is with us" (Des Pres 1976, p. 170). As we listen to the survivors' testimony, voices alien to our own creep into our throats and bring with them the silence of the One whom we cannot escape and yet who eternally eludes us. This depth dimension of our inner being, the eternal aspect of the memory and the testimony, is made of a question without answer. Thus "the Jew and his questioning," Wiesel asserts, "are one" (Wiesel 1970b, p. 214). Which is to say: the Jew and his memory, the Jew and his testimony, the Jew and his tradition are one.

Because the literary response to the Holocaust comes to us not only in a tale of horror but also in an affirmation of humanity, as we read each response we hear a calling and a commandment. The witnesses, the authors, place in our care a message that was placed in their care-and more: they place in our care both the cry of the murdered that haunts them and the call of a future, the call of life, that summons them. As their readers, then, not only do we receive the tale of a life, but we now must live in a certain manner. As more and more and more of these survivors pass on, more and more are we turned over to the situation of one who says Kaddish for his deceased parent and adds, "Hareyni kaparat mishkavo-May I be an atonement for his rest." How do we do that? By taking the literary response to the Holocaust in hand and by living according to the teaching that defines it, the teaching that the other human being harbors an infinite dearness that places upon us an infinite responsibility-what Emmanuel Levinas calls "the exigency of the Holy" (Levinas 1985, p. 105). Living a life in keeping with this teaching is part of the message that 
we must deliver, not only with our words but also with our deeds, so that the messenger himself, the reader herself, is part of the message.

A fundamental form of the literary response to the Holocaust is the Holocaust memoir. If the survival of a memoir's author is a miracle, the memoir itself is an even greater miracle. For in the act of writing the memoir the author attests to the infinite dearness of the other human being after emerging from a realm in which the human being was less than human. Contrary to the abuser who abuses because he was abused, these are people who transform unspeakable suffering into ineffable blessing - not so they can feel better about themselves but for the sake of their heirs. In the literary response to the Holocaust, then, one discovers a fulfillment of what Emil Fackenheim describes as the 614th Commandment, namely the injunction to bear Jewish life into the world, even - or especially-if the world may be hostile to that life-not just to deny the Nazis a posthumous victory but to take up the millennial testimony to the dearness of life that Jews are chosen to bear. The reader is transformed into a messenger because, in the process of reading, he or she comes into the presence of what Fackenheim calls the Commanding Voice of Auschwitz (Fackenheim 1978, p. 19ff). The commandment that silently resounds in that Voice is part of the message: the message delivered is an imperative.

This imperative can be seen in the survivor's literary account of a lifetime that exceeds the deathtime of the anti-world, a life that includes children and grandchildren, as well as the memory of a mother and father whose love and teaching are passed on to the next generation. Which means: the literary response to the Holocaust is more than just an eyewitness account offered to the world-it is bequeathed to us by the mothers and fathers of a generation. That is the difference between a report and a memory transmitted through literature: a report we file away, a memory we inherit. In our own time the survivors' testimonies come to a generation of children who have grown up to become parents and grandparents. What, then, shall we tell our children and our grandchildren, not only about the Holocaust but about those who survived it? That their lives were empty, the world is a void, and life is meaningless-just look at the Holocaust? And how shall we tell them what cannot be told, what eludes utterance? Is it not through our own literary response to the testimony itself? The witnesses who offer up their literary response to the Holocaust through memoirs, poetry, and fiction not only lived through it - they relive it and go on living in spite of it, to bring us a truth and a teaching concerning what is most precious and most dear. What will become of their testimony? Will it become a shriek of silence or a commanding voice? This is not an either-or proposition; to be sure, Holocaust testimony contains both the voice of the survivor and the silence she survived. The question is: how do we attend to the voice without being swallowed up by the silence? The answer: by transmitting the message from our mothers and fathers as mothers and fathers. How do we do that? By living lives worthy of their lives, by attesting to the value of their lives through a testimony to the infinite dearness of the lives around us-by engaging this literary response to the Holocaust.

Donna Rubinstein heard this summons arising from her dead parents long before Fackenheim formulated the 614th Commandment: "An inner voice whispered, 'Don't leave our heritage. Don't forget the past ... . You have a deep responsibility to your parents, to all of your family lying in unmarked graves. Don't contribute to Hitler's cause by helping to decimate Judaism and the Jewish people'" (Rubinstein 1982, p. 87). Once again, we find in this summons the connectedness, through the family, to humanity and to God. The response to the summons, then, is made not only to the dead but also to the One in whose image they were created-that is what makes her literary response a testimony. That is what transforms the reader into a witness. Like the "bloods" of Abel that cried out to God, as it is written in the plural in the biblical verse (Genesis 4:10), the "bloods" of these dead cry out to God through the voices of human beings, in tales that bespeak what both God and humanity are afraid to know. The literary response to the Holocaust, then, functions as a narrative, by which the author narrates her own life through the narration of life lost. And 
what speaks in that narrative speaks not in so many words but in the process of narration itself. The narrative process transforms the reader into a messenger-and a storyteller.

Early in her memoir Gisella Perl writes, "I offer this book as a monument commemorating ... Nazi inhumanity and the death of their six million innocent Jewish victims" (Perl 1948, p. 12). But soon she realizes that she has been called not just to commemorate events but to narrate stories, and that is where her literary response comes to bear. "Those six million dead are so many terrible, heartbreaking stories," she asserts. "Every one of them represents not only the second of death, however horrible that is, but an entire, colorful, exciting human life, a past, and what is more, a future" (Perl 1948, p. 137). The literary response to the Holocaust is about that future. Gerda Klein begins with this realization: "I am haunted by the thought that I might be the only one left to tell their story" (Klein 1957, p. vii). Two things must be noted in these passages. First, the tale they are summoned to tell is not only the tale of life lost in the past but of life never lived in the future; it has a double reflection, a double orientation. Second, the survivor has a sense that she alone is the one summoned to tell this story; her past and future lie in this having been singled out for this response, which is a literary response, and not just a journalistic report, as response that conveys the ineffable. As it happens with the survivor, the summons of the dead singles me out for this responsibility and for this substitution. $I$, the reader, must become the voice of the murdered: this $I$ is the $I$ of the reader transformed into a messenger.

The voice of the messenger is in a sense a substitute for those who cannot speak. The word substitute derives from the Latin sub, meaning "in place of," and statuere, meaning "to cause to stand." The voice that substitutes for the voices of the dead does not stand in their place but causes them to stand in place, creating a place where those who are absent may find a certain presence. Mourning both the death of her loved ones and their absence, Lily Lerner writes, "They have gone from the earth completely. They, and those like them, both Jew and Gentile, are why I force upon myself the torture of remembering" (Lerner 1980, p. 13). Not only are the dead present in her memory, but her memory, embodied in her literary response, imparts a presence to the dead by making their summons heard through her own act of response and remembrance; only one who is in some sense present can be heard. This hearing, this assignation, this summons that transforms her into a witness resounds throughout Frida Michelson's testimony. "I must survive as a witness," she asserts (Michelson 1979, p. 42). For the voices speak to her, insisting, "There, before your window, before your eyes, the tragedy of your whole nation is being played out. Remember. Do not forget!" (Michelson 1979, p. 78). The summons of the dead enables a person to survive hardship that would otherwise be fatal; it can lead the living to walk among the dead. When Miklos Nyiszli, for example, was a doctor in Auschwitz the summons of the dead drew him into the crematorium, into the very gullet of the death factory. "I felt it my duty," he relates, "to be able to give an accurate account of what I had seen if ever, by some miraculous whim of fate, I should escape" (Nyiszli 1960, p. 75). Whence arises this duty? From the muted cries of the dead that are heard above the roaring flames of the ovens, heard precisely through the literary response to the Holocaust. Inasmuch as the cries of the dead are heard in the witness's voice as they resound through his literary response to the Holocaust, they, again, transform the reader into a messenger.

Those of us who were not turned over to the Kingdom of Night are situated along its edges by the witnesses who transmit that summons; we too are subject to the 614th Commandment. We not only receive this testimony; we, as readers, are issued this summons, entrusted with the lost lives and the lost outcries that haunt this memory. That is why Elie Wiesel urges, "Perhaps every Jew ought to pick a dead man, woman, or child, whether known or unknown, and say: from this point on, I shall live for myself and for him or her" (Wiesel 1990a, p. 37). For these dead have already picked us through the testimony of the surviving remnant. In the Auschwitz Museum one can see the mounds of hair shorn from the last groups of women sent to the gas chambers; that hair continues, in the words of Primo Levi, "to whisper its mute accusation to the visitor" (Levi 1988, p. 124). Why accusation? Because the visitor arrives too late, always too late. The readers of these 
literary responses to the Holocaust arrive too late. Too late we read the testimony of the survivors and the summons of the dead. Too late we struggle to respond to what was. Too late we deliver the message.

\section{What Is at Stake}

What is at stake in transmitting the message that transforms the reader into a messenger is precisely what the Nazis intended to exterminate in the extermination of the Jews: the life of the soul, the absolute nature of ethical exigency, and our ineluctable connection to the other human being, as taught in the Jewish teaching and tradition slated for annihilation. According to Judaism, every human being is my fellow human being, indeed, is part of my family, descended as we are from a single human being. Rabbi Shimon ben Azzai maintained that the origin of all humanity from one human being is the most fundamental of all Jewish teachings (Talmud Yerushalmi, Nedarim 9:4). Why did God begin humanity with just one human being, and not two? The sages say it was so that no one may declare to another, "My side of the family is better than your side of the family" (Tosefta Sanhedrin 8:4). There is only one side of the family, which means that all of humanity is interrelated, physically through Adam, metaphysically through the Creator. To be sure, the Hebrew word for "human being" is ben adam, a "child of Adam." There is no teaching more inimical to National Socialism's most fundamental claim-namely that there is no connection between the Aryan and the non-Aryan-than this teaching that defines Judaism.

The summons of the dead is part of this Jewish teaching, part of a sacred past that imparts significance and substance to our present; history is revelation, so that answering to the summons of the dead, as we have seen, entails the receiving of God's Word in the form of God's Commandment. The ultimate aim of revelation is redemption at some time that is yet to be, and our response to the yet unborn is part of our relation to the promise of redemption. If the literary response to the Holocaust seeks a recovery of the tradition slated for annihilation, it seeks a recovery of revelation. Belonging to a future ever yet to be revealed, the unborn signify the full, redemptive revelation of the Face that was hidden from Moses when God passed before him (see Exodus 33: 20-23).

Here, too, if we allow ourselves a midrashic elaboration, we see the Commanding Voice at work. For we are told in the Talmud that when Moses stood in the cleft of the rock and looked upon God's back, he saw the knot formed by the straps of the tefillin on the back of God's neck (Menachot 35b). We may assume, then, that on His forehead, between His eyes, was the frontlet or the box in which His Word is hidden away, the redemptive Word withheld from Moses and yet to be revealed. In the tefillin are the words we offer and the words we seek in our tefillah, in our "prayer." And our prayer is offered in response to summons of the revealed and the yet to be revealed, of the back and the face-of the dead and the unborn. The summons of the unborn, then, is the "other side" of the summons of the dead. As we receive the word of the dead, the fate of the unborn is placed in our care: the children who signify the potentiality of redemption stand as sureties that we shall abide by the revelation. This very point, in fact, is made in the Midrash on Psalms (Braude 1959, vol. 1, p. 125). There we are told that when God was about to offer His Torah to the Israelites, He asked them what they would put up as collateral to ensure their remembrance and observance of the Torah.

"The Patriarchs," they replied. "We offer them as sureties for what we are about to receive, for they received the Covenant."

"No," God refused. "They are already in My debt."

"The Prophets," the Israelites offered. "They will stand as sureties, for they are the most righteous of men."

"No," God repeated. "They too have debts of their own."

Finally, after a moment of hesitation and reflection, the Israelites said, "We give You our children. For they are without sin." 
God then asked the infants at their mothers' breasts and the embryos within the womb, "Will you be sureties for your fathers and mothers, so that if I give them the Torah they will live by it, but that if they do not you will be forfeited because of them?"

And they answered, "Yes."

So, one sees what is at stake in the reader's being transformed into a messenger: answering to the dead, the reader of the literary response to the Holocaust now answers for the unborn. The testimony offered on behalf of family, friends, and others no longer present is addressed to strangers yet to be present. Part of what Lily Lerner calls "the torture of remembering" (Lerner 1980, p. 13) lies in not knowing who will receive the testimony or even whether it will be received. While the dead robbed of their cemeteries cry out for burial, the unborn issue a summons for birth. But the unborn stand as sureties for the truth of the testimony, so that the survivor speaks in a profound movement of faith. Suddenly the 614th Commandment to preserve the Jewish faith returns us to the First Commandment to have children (Genesis 1:28). Through this relation to the as yet unborn and in the hearing of their summons, the Jewish faith, the Jewish people, and the Jewish person are eternally reborn. From a Jewish perspective, however, this possibility entails not only an inner miracle but also an outward manifestation of that miracle: the new birth by which the self becomes other to itself is not simply a rebirth of the soul but the birth of another, the birth of a Jewish child.

If the summons of the dead that rises up from the literary response to the Holocaust is a cry of "Remember," the summons of the unborn is a cry of "Live!" And human beings can live, that is, can regenerate their being, only by bringing another being into the world: that is the message of the reader transformed into a messenger. In this participation in the Creation the messenger declares with the Creator who summons us to this bearing of children, "Ki tov! It is good!" In the literary response to the Holocaust the "not yet" of time is manifested precisely in the summons to paternity. Indeed, the Nazis systematically sought to destroy Jewish being by destroying Jewish paternity; one way in which they carried this out was through various forms of sterilization. In the end pregnancy itself was a capital crime: if the crime of the Jew was being in the world, then the most heinous of criminals is the Jewish mother. This measure was aimed not at population control but at population eradication and thereby at the eradication of the witnesses to the Creator of life. Fania Fénelon relates that when the women in the murder camp ceased having their menstrual periods, they prayed to be free from "this curse the Germans were holding over us: sterility" (Fénelon 1977, p. 89). Just as the Nazis tried to murder the Jewish dead, so did they undertake a Slaughter of the Innocents in the murder of the Jewish unborn. The unborn too, therefore, are among the victims whose summons transforms the reader into a messenger.

Looking at other literary testimonies, we find that the summons of the unborn, like the summons of the dead, arises both during the ordeal in the anti-world and after the return to what was left of the world. Gerda Klein, for example, writes, "The idea returned that someday I must have a baby of my own. I felt that I would endure anything so long as that hope was not extinguished" (Klein 1957, p. 156). While Pelagia Lewinska "felt under orders to live" when faced with Nazi atrocity (Lewinska 1968, p. 150), Gerda Klein felt summoned to bear life. And Fackenheim's comment on Lewinska's response applies equally to Klein's resolve. "Whose orders?" Fackenheim asks. "Once again “willpower' and 'natural desire' are both inadequate. Once again we have touched an Ultimate" (Fackenheim 1989, p. 218). Whose orders? The orders of the Ultimate, of the Holy One, who calls upon us to bear life (Genesis 1:28) and to choose life (Deuteronomy 30:19).

Thus He summons us endlessly and despite ourselves, through those created and yet to be created in His holy image. After her release, then, after she was "safe" and "free" to do as she wished, Kitty Hart came to a realization: "A family of my own-that is what I must build" (Hart 1982, p. 16). Reading the word build in this declaration of life, one recalls a passage from the Talmud: "R. Eleazar said in the name of R. Hanina: 'The disciples of 
the wise increase peace in the world, as it says, "All thy children shall be taught of the Lord, and great shall be the peace of thy children" [Isaiah 54:13]. Read not banayikh (thy children) but bonayikh (thy builders)'" (Berakhot 64a). Kitty Hart, too, is a disciple of the wise: building a family, she builds peace by bearing children. "Peace," or shalom in Hebrew, is tied to "wholeness" or shlemut. Any wholeness that may be recovered in the world entails the recovery of children. For they are the builders of peace and wholeness. They are the ones who transform the reader into a messenger. For they are the primary recipients of the message. It is not a question of God's performance of miracles despite the natural order but of the human being's transformation of the natural order into the miraculous. If it were just a matter of returning the dead to life, we could simply wait until the blowing of Gabriel's horn. In short, there would be no need for this testimony.

Thus, in his literary response to the Holocaust that transforms his reader into a messenger, Samuel Pisar writes, "It is our children that I have in mind as I write this book, a book that is not about the past, but about the future" (Pisar 1979, p. 23). Why about the future? Near the end of his memoir, he explains: "When I see mankind heading once more toward some hideous collective folly, I feel that I must either lapse into total silence or broadcast to the world my urgent sense of the horrors that threaten to destroy our own and our children's future" (Pisar 1979, p. 304). What is at stake in the literary response to the Holocaust, what is to be recovered again and ever again, is not the grand future of the world or of an anonymous humanity but the future of this single child. Recall in this connection the words from the last pages of Isabella Leitner's memoir. There she remembers her late mother by linking her mother to her first-born child Peter and to children yet to be born; in this way she makes the summons of the dead and the summons of the unborn into a single summons to bear witness. "Mama, I'm pregnant!" she cries. "There is another heart beating within that very body that was condemned to ashes ... . [We've] started the birth of a new six million" (Leitner 1978, p. 96). The one who had been marked as a corpse becomes the vessel of a seed, and the seed is the vessel of generations. Her child has that much in common with Isaac. The knife was raised over him, however, before he was born, and not by his father but by the murderer of the father.

Leitner's child may have one thing more in common with Isaac. For it was Isaac's privilege, as Wiesel has pointed out, to remain the defender of Israel by transforming suffering "into prayer and love rather than into rancor and malediction" (Wiesel 1976, p. 97). This transformation is the aim of the reader transformed into a messenger. And it can be wrought only by a faith that comes despite all: the summons of the unborn is a call to faith. "From the heart of 'no,'" André Neher observes, "there arises a 'yes.' Faith is a genesis; it appears ex nihilo" (Neher 1981, p. 207). The heart of "no" is as bottomless as the pit of the anti-world, and the one transformed into a messenger must eternally return to that nothingness if he or she is to transform "no" into "yes" and malediction into benediction.

\section{The Multi-Faceted Literary Response to the Holocaust}

This Special Issue of Humanities contains an eclectic variety of scholarly analyses of the many forms of literary responses to the Holocaust. The Special Issue opens with Victoria Aarons' study of an innovation form of Holocaust literature, the graphic novel. From this American example of a subsequent generation's response, we go to Ranen Omer-Sherman's investigation of the later generation's literary response in Israel, focusing on the narratives of Nava Semel, David Grossman, and Etgar Keret. Then, we go back in time to Phyllis Lassner's piece on fiction written during the Third Reich, showing that the literary response to the Holocaust begins with an anticipation of the Holocaust.

In a study of how non-Jewish authors take up a literary response to the Holocaust, Rachel Brenner next offers an analysis of Yann Martel's Beatrice and Virgil. From Rachel Brenner we go to Bridget Menard, who focuses her analytical skills on the short stories of Ida Fink, followed by Bjorn Krondorfer's examination of the ethical "gray zone" found in literary testimonies. Next comes an analysis of the relationship between literary memory 
and the literary response to the Holocaust in Nathaniel Parker Weston's analysis of memoirs from Central Europe. Following Weston's article, Blake Remington's piece explores the ethical imperatives that define Holocaust literature.

From there we go to Shannon Quigley's article on Elie Wiesel's Night, where she elucidates a prominent theme in one of the Holocaust's most prominent memoirs, namely the theme of the relation between father and son and its implications for a post-Holocaust understanding of the "father-son" religions, Judaism and Christianity. Moving from Wiesel's memoir, Traci S. O'Brien takes us to H. G. Adler's discourse on writing literature in the aftermath of the Holocaust as a literary response to the Holocaust. J. E. Wolfson then into a woman's memoir in his deft analysis of ethical aspects of Fania Fénelon's Playing for Time, which in turn brings us to the thinking of the most prominent ethicist to respond to the Holocaust, Emmanuel Levinas, the subject of Karl Sen Gupta's essay, the last essay in this Special Issue.

\section{Closing Thoughts}

The testimonial literary response to the Holocaust is about memory-memory of the past for the sake of the future. We live only by looking to the future because only in this realm of the yet-to-be do we discover a direction that instills life with the meaning that came under assault in the Holocaust. And so we realize that the assault on meaning-the assault on the soul-is an assault on time, that is, on the future. Targeting the future for destruction, the Nazis attempted to destroy memory. Indeed, both Primo Levi $(1988$, p. 31) and Elie Wiesel (1990a, p. 155) have described the Nazi project as a war against memory. Thus, the cry of "Remember!" that we find, for example, in Bertha Ferderber-Salz's literary response to the Holocaust is much more than a summons; it is an essential part of an open-ended struggle for the recovery of meaning, time, and memory. She writes, "Until my last breath I will pray for the world to stop the insanity of hatred. I am not yet old, but I am very tired. When my time is up I will shout with all my strength, 'Remember and don't forget! Please, don't forget!'" (Ferderber-Salz 1980, p. 232). The urgency of the summons to the listener is overwhelming. The memory underlying Holocaust testimony has nothing to do with the self-indulgent reminiscence of nostalgia. No, it is a memory that exceeds remembrance to transform the listener into a messenger.

"Because I remember, I despair," says Wiesel. "Because I remember, I have the duty to reject despair" (Wiesel 1990b, p. 248). With tears of despair we listen to the testimony. Transformed into a messenger, we must respond to it with the resolve of affirmation. "Why is the water of the eyes salty?" the Midrash asks. "Because if a man wept for the dead continually his eyes would soon be blinded" (Freedman and Simon 1961, vol. 7, p. 740). And he could not see the future to which he must look and into which he must lead his children. For the Jew, that future lies not in the hereafter of heaven but in the here of this earth - that is where the Jew engages in his life-affirming testimony. That is where the Jew delivers his message: the earthly realm is the realm of the Covenant and the place to which the Ark of the Covenant is entrusted. Why? Because the earth is the realm of time and testimony and therefore of the meaning that memory eternally seeks. "The Ark of the Covenant," Rashi reminds us, "is referred to as the Great Searcher" (Rashi 1972, vol. 4, p. 100a). The Ark of the Covenant, then, is the Ark of Testimony, for there is no searching greater or more sublime than the searching found in the eternal movement of testimony. And the summons that transforms the reader into a messenger comes not only from beyond but, more profoundly, from within.

Listen: On 26 April 1986 a disaster occurred in Chernobyl, when a cloud of radioactive material was released into the air from one of the chimneys at a nuclear power plant. Two weeks later radiation levels in Montana were elevated. In the time of the Shoah the smoke of from the burning bodies of the Jewish people bellowed into the air not for one day but for a thousand days, not from one chimney but from dozens. The winds have spread the ashes of those Jews over the face of the earth. They inhabit the soil from which we harvest our bread. They abide in the bread we put into our mouths. As we are made of that bread, 
so are we-all of humanity - made of those ashes: we are the grave to those denied a grave. The ashes nag. And in their nagging abides a nagging question: What will you make of us? Only as a messenger, and not merely as a reader, can we respond to that question.

In his literary response to the Holocaust survivor Arnošt Lustig puts it this way in his novel A Prayer for Katerina Horovitzova:

These ashes would be indestructible and immutable, they would not burn up into nothingness because they themselves were remnants of fire ... No one living would ever be able to escape them ... These ashes will be contained in the breath and expression of every one of us and the next time anybody asks what the air he breathes is made of, he will have to think about these ashes; they will be contained in books which haven't been written and will be found in the remotest regions of the earth where no human foot has ever trod; no one will be able to get rid of them, for they will be the fond, nagging ashes of the dead who died in innocence. (Lustig 1973, pp. 50-51)

The ashen remains of Israel were cast to the winds, and the winds have scattered them over the face of the earth. They sleep in the earth from which we harvest our bread, and they abide in the bread that we place in our mouths. Thus, we see how the ontological order has been twisted: the Jewish remnant from the Kingdom of Night-humanity itself-has become the cemetery for the Jewish dead.

Funding: This research received no external funding.

Conflicts of Interest: The author declares no conflict of interest.

\section{References}

Braude, William G. 1959. Midrash on Psalms. 2 vols. New Haven: Yale University Press.

Des Pres, Terrence. 1976. The Survivor: An Anatomy of Life in the Death Camp. New York: Oxford University Press.

Fackenheim, Emil L. 1978. The Jewish Return into History. New York: Schocken.

Fackenheim, Emil L. 1989. To Mend the World: Foundations of Post-Holocaust Jewish Thought. New York: Schocken.

Fénelon, Fania. 1977. Playing for Time. Translated by Judith Landry. New York: Atheneum.

Ferderber-Salz, Bertha. 1980. And the Sun Kept Shining. New York: Holocaust Library.

Freedman, H., and Maurice Simon, transl. and eds. 1961, Midrash Rabbah. 10 vols. London: Soncino.

Hart, Kitty. 1982. Return to Auschwitz. New York: Atheneum.

Ka-tzetnik 135633. 1989. Shivitti: A Vision. Translated by Eliyah De-Nur and Lisa Herman. New York: Harper.

Katznelson, Yitzhak. 1972. Vittel Diary, 2nd ed. Translated by Myer Cohn. Tel-Aviv: Hakibbutz Hameuchad.

Klein, Gerda Weissmann. 1957. All but My Life. New York: Hill and Wang.

Leitner, Isabella. 1978. Fragments of Isabella. Edited by Irving Leitner. New York: Thomas Crowell.

Lengyel, Olga. 1972. Five Chimneys. London: Granada.

Lerner, Lily Gluck. 1980. The Silence. Secaucus: Lyle Stuart.

Levi, Primo. 1988. The Drowned and the Saved. Translated by Raymond Rosenthal. New York: Vintage Books.

Levi, Primo. 1990. Survival in Auschwitz: The Nazi Assault on Humanity. Translated by Stuart Woolf. New York: Simon \& Schuster.

Levinas, Emmanuel. 1985. Ethics and Infinity. Translated by Richard A. Cohen. Pittsburgh: Duquesne University Press.

Lewinska, Pelagia. 1968. Twenty Months at Auschwitz. Translated by A. Teichner. New York: Lyle Stuart.

Lustig, Arnošt. 1973. A Prayer for Katerina Horovitzova. Translated by Jeanne Nemcova. New York: Harper \& Row.

Michelson, Frida. 1979. I Survived Rumbuli. Translated by Wolf Goodman. New York: Holocaust Library.

Neher, André. 1981. The Exile of the Word. Translated by David Maisel. Philadelphia: Jewish Publication Society.

Nyiszli, Miklos. 1960. Auschwitz: A Doctor's Eyewitness Account. Translated by Tibere Kremer and Richard Seaver. New York: Fawcett Crest.

Perl, Gisella. 1948. I Was a Doctor in Auschwitz. New York: International Univ. Press.

Pisar, Samuel. 1979. Of Blood and Hope. Boston: Little, Brown and Co.

Rashi. 1972. Commentary on the Torah. Translated by M. Rosenbaum and A. A. Silbermann. 5 vols. Jerusalem: The Silbermann Family. Rubinstein, Donna. 1982. I Am the Only Survivor of Krasnostav. New York: Shengold.

Tillion, Germaine. 1975. Ravensbrück. Translated by Gerald Satterwhite. Garden City: Doubleday.

Trepman, Paul. 1978. Among Men and Beasts. Translated by Shoshana Perla and Gertrude Hirschler. New York: Bergen Belsen Memorial Press.

Vinocur, Ana. 1976. A Book without a Title. Translated by Valentine Isaac and Ricardo Iglesia. New York: Vantage.

Wiesel, Elie. 1970a. A Beggar in Jerusalem. Translated by Lily Edelman and Elie Wiesel. New York: Random House.

Wiesel, Elie. 1970b. One Generation After. Translated by Lily Edelman and Elie Wiesel. New York: Pocket Books. 
Wiesel, Elie. 1976. Messengers of God. Translated by Marion Wiesel. New York: Random House.

Wiesel, Elie. 1990a. Evil and Exile. Translated by Jon Rothschild. Notre Dame: Univ. of Notre Dame Press.

Wiesel, Elie. 1990b. From the Kingdom of Memory. Translated by Marion Wiesel. New York: Summit.

Wiesel, Elie. 2006. Night. Translated by Marion Wiesel. New York: Hill and Wang. 